\title{
A QUANTITATIVE ASSESSMENT OF THE IMPACT OF GOVERNMENT ACTIVITIES ON THE ECONOMY OF POLAND
}

\author{
Daniel Francois Meyer \\ North-West University, South Africa
}

\begin{abstract}
Government interventions and economic-related activities may have significant impacts on the economies of countries. Effective governance and quality institutions are required for sustainable economic growth in both developed and developing countries. The primary objective of this study was to analyse the impact of government activities on economic growth in Poland. The study followed a quantitative research approach, employing time series data from 1995 to 2017 including GDP as the dependent variable with variables such as government spending and debt, size and effectiveness of government, and the level of corruption as independent variables. The relationships between the variables were analysed by making use of an Auto-Regressive Distributed Lag (ARDL) econometric model. The results indicated that there are both long- and short-run relationships between the variables. Other results indicated that government variables included in the study caused changes in economic growth as assessed via a Granger causality analysis. Several recommendations were listed which include inter alia, that effective government spending and management have a positive impact on the economy, while efforts to limit the levels of corruption also contribute to economic improvements in a country.
\end{abstract}

Keywords: economic output, government activities, Poland, time series analysis

DOI: http://dx.doi.org/10.15549/jeecar.v6i2.338

\section{INTRODUCTION}

On a global scale, governance and governments, and this includes politics, have a significant impact on most economies. In addition, stabile governance and politics may have a positive impact on the macro-economic environment. Ineffective governance and public institutions play critical roles in poor economic growth and development performance (World Bank, 2000). This paper has the specific objective to analyse the relationships between government activities and governance issues and economic growth measured as gross domestic product (GDP). Good governance appears to be at the centre of growth and development. Effective government activities, including economic activities, is only possible through good governance and quality institutions (Grindle, 2007; Sambumbu \& Okanga, 2016). Effective and good governance have been used as interchangeable concepts and this relationship has been used to assist in explaining both concepts (Andrews, 2008). Effective government needs to ensure fiscal discipline, have a decentralized governance system, reacts to the basic needs of citizens and formulate and implement enabling environment policies (Andrews, 2008). The literature review 
indicates limited analysis of the concept of the relationship between government activities and the relationship with economic growth, especially using a quantitative methodology, indicating a gap in the research.

This study focuses on the governance and economic growth situation in Poland. Table 1 is a summary of key data for the country. Poland has been selected due to its successful transition from a socialistic country to a modern democratic country in just over two decades (Nölke \& Vliegenthart, 2009), to become a leading country in Central and Eastern Europe. The country demonstrated its economic strength during the financial crises when it remained the only European country that achieved significant positive economic growth during this period. Poland's economy has, over the last decade, revealed strong growth with good and effective macro-economic policy. Poland is classified by the UN as a high income developed country and is the sixth largest economy in the EU region (UN, 2017). Economic transformation actions included trade liberalization, business development incentives, reduction of regulations and substantial investments in critical economic sectors such as infrastructure, defence, and energy. Governance issues such as, political influence on the judiciary and existence of corruption are problems that need to be addressed. Aspects for continued growth include the removal of backlogs in infrastructure: roads, rail and energy, and the relaxation of strict labour regulations, and solutions to migration of young people to other EU member states (The Heritage Foundation, 2017; CIA, 2017).

Table 1. Key indicators: Poland

\begin{tabular}{|l|l|}
\hline Indicator & Poland \\
\hline GDP (annual growth rate) & $\$ 586$ billion $\left(22^{\text {nd }}\right)^{*}$ \\
\hline GDP per capita & $\$ 12700$ \\
\hline Gini Index (a value closer to 0 indicates income equality) & 31.9 \\
\hline HDI (values between 0 and 1) & 0.860 \\
\hline Population (growth in brackets) & 38.4 million $(-0.1 \%)$ \\
\hline Life expectancy & 76.9 \\
\hline Youth unemployment & $19.9 \%$ \\
\hline Economic Freedom index (values between 0 and 100) & $68.3(45)^{*}$ \\
\hline Global competitiveness index (values between 0 and 10) & $4.56(36)^{*}$ \\
\hline Happy planet index (values between 0 and 100) & $27.3(62)^{*}$ \\
\hline Global entrepreneurship index (values between 0 and 100) & 50.4 \\
\hline $\begin{array}{l}\text { Global corruption index (values between 0 and 10 with a higher } \\
\text { value indicating lower levels of corruption) }\end{array}$ & 6.3 \\
\hline Global efficient government index (values between 0 and 100) & 87.8 \\
\hline Global political stability index (values between -2.5 and 2.5) & 0.88 \\
\hline
\end{tabular}

Note: * Indicates global ranking in brackets where applicable.

Source: CIA, 2017; NationMaster, 2017; United Nations, 2017; World Bank, 2017.

Table 2 provides a comparative summary of the key economic and governance indicators for the VISEGRÁD group of countries. In terms of overall GDP, Poland is by far the largest with the highest growth rates followed by the Czech Republic with Slovakia being the smallest of the four countries. In terms of GDP per capita, the Czech Republic has the highest value followed by Slovakia, while Poland again had the highest annual growth of $4.5 \%$ followed by Hungary. As the largest country and economy, Poland also has by far the highest government expenditure followed by the Czech Republic. The four countries all have relatively low levels of government expenditure to GDP ratios of between 17.7\% (Poland) to 19.9\% (Czech Republic). The government debt situation across the four countries also seems healthy with a 
diminishing trend. Hungary at $87.8 \%$ debt to GDP ratio and Poland at $66.1 \%$ are both on the high side but with a downward trend. Regarding the various governance indices, the Czech Republic has the finest index for accountability, corruption control and effective governance, as well as for size of governance and level of regulations. In terms of the indices, the Czech Republic has the overall highest level of governance. Poland has, in general terms, moved backwards for most.

Table 2. Comparative summary of key indicators for VISEGRÁD Countries

\begin{tabular}{|l|c|c|c|c|c|c|c|c|}
\hline \multicolumn{1}{|c|}{ Variable } & \multicolumn{2}{c|}{ Poland } & \multicolumn{2}{c|}{$\begin{array}{c}\text { Czech } \\
\text { Republic }\end{array}$} & \multicolumn{2}{c|}{ Hungary } & \multicolumn{2}{c|}{ Slovakia } \\
\hline Period in years & 2015 & 2018 & 2015 & 2018 & 2015 & 2018 & 2015 & 2018 \\
\hline $\begin{array}{l}\text { GDP (Billion USD at constant } \\
\text { prices (annual growth \% from } \\
\text { 2015 to 2018 in brackets) }\end{array}$ & 556.4 & $\begin{array}{c}631.9 \\
(4.5)\end{array}$ & 225.5 & $\begin{array}{c}248.0 \\
(3.4)\end{array}$ & 144.2 & $\begin{array}{c}161.2 \\
(3.9)\end{array}$ & 101.6 & $\begin{array}{c}112.6 \\
(3.6)\end{array}$ \\
\hline $\begin{array}{l}\text { GDP per capita (constant } \\
\text { prices USD) (annual growth \% } \\
\text { from 2015 to 2018 in } \\
\text { brackets) }\end{array}$ & 14646 & $\begin{array}{c}16639 \\
(4.5)\end{array}$ & 21381 & $\begin{array}{c}23344 \\
(3.1)\end{array}$ & 14653 & $\begin{array}{c}16503 \\
(4.2)\end{array}$ & 18737 & $\begin{array}{c}20669 \\
(3.4)\end{array}$ \\
\hline $\begin{array}{l}\text { Government expenditure } \\
\text { Billion USD at constant prices } \\
\text { (Expenditure as \% of GDP in } \\
\text { brackets) }\end{array}$ & 98.2 & $\begin{array}{c}108.4 \\
(18.0)\end{array}$ & $\begin{array}{c}43.3 \\
(19.7)\end{array}$ & $\begin{array}{c}46.7 \\
(19.9)\end{array}$ & $\begin{array}{c}(19.9 \\
(19.8)\end{array}$ & $\begin{array}{c}(19.1) \\
(19.1\end{array}$ & $\begin{array}{c}19.1 \\
(19.1)\end{array}$ \\
\hline Government debt as \% of GDP & 69.9 & 66.1 & 52.1 & 43.9 & 99.4 & 87.8 & 59.7 & 58.2 \\
\hline $\begin{array}{l}\text { Accountability index } \\
\text { (between -2.5 and +2.5) }\end{array}$ & 1.04 & 0.78 & 1.04 & 0.97 & 0.56 & 0.37 & 0.97 & 0.94 \\
\hline $\begin{array}{l}\text { Corruption control index } \\
\text { (between -2.5 and +2.5) }\end{array}$ & 0.67 & 0.73 & 0.43 & 0.57 & 0.15 & 0.09 & 0.18 & 0.22 \\
\hline $\begin{array}{l}\text { Effective governance } \\
\text { (between -2.5 and +2.5) }\end{array}$ & 0.80 & 0.63 & 1.05 & 1.02 & 0.50 & 0.51 & 0.84 & 0.81 \\
\hline $\begin{array}{l}\text { Size of government (Max 10/ } \\
\text { Min 0) }\end{array}$ & 5.73 & 5.62 & 5.22 & 5.77 & 5.32 & 4.89 & 5.60 & 5.59 \\
\hline $\begin{array}{l}\text { Level of regulations (Max 10/ } \\
\text { Min 0) }\end{array}$ & 7.69 & 7.59 & 7.96 & 8.09 & 7.53 & 7.63 & 7.54 & 7.58 \\
\hline
\end{tabular}

Source: World Bank, 2018.

\section{LITERATURE REVIEW}

Several different definitions exist for good governance, indicating uncertainty on the meaning of the concept. Good governance is defined by Besancon (2003) as the effective provision of services to all citizens. Such services include security, rule of law, civil freedom, health care, education, infrastructure, fiscal system, and an enabling regulatory environment. According to the UNDP (1997), good governance includes the following: good management processes; the implementation of political and administrative management; effective institutions with quality systems; and a focus on best practice principles such as, public participation, openness, accountability, effectiveness and rule of law. According to Andrews (2008), an effective government possesses the following: be small in extent with limited intervention in the economy; a clear vision and processes; committed quality personnel that formulate and implement policies and projects; comprehensive participation with the public; efficient financial management; responsive, transparent and decentralized structures and political stability. The key concepts that define good governance include the assurance of the rule of law, 
efficiency, accountability (IMF, 2005), political stability, implementable government policy, macro-economic policy (DFID, 2001), democracy, citizen participation, and anticorruption (USAID, 2005).

From a theoretical perspective, various theories have been formulated in the past on the role and impact of government actions and activities on the economy. The predominant of is the Keynesian Theory of aggregate demand with government expenditure seen as a major component of the total economy (Eichner \& Kregel, 1975). In addition, the "Big Push" theory as developed by Rosenstein-Rodan, (1961), which promoted the idea of coordination of all role players in the economy with the lead being taken by government and effective policy. Equally, the theory of "formal rule-bound governance" with well-defined roles and functions that provides an enabling environment for businesses to prosper and have confidence in government (Andrews, 2008). Kaufmann et al. (2007) state that good governance relates to limited government intervention, providing inputs in the growth and development in social and developmental factors. Many researchers have listed characteristics of good governance (Arndt \& Oman, 2006; Thomas, 2007; Brinkerhoff \& Goldsmith, 2005) and may include: limited government interventions (Sutopo \& Siddi, 2018); formal structures with roles and functions; quality non-political officials; effective implementation of policy and service delivery; fiscal discipline; red-tape reduction processes; pro-business; decentralized and participatory (Meyer \& Meyer, 2016). Nash et al. (2006) formulated a set of criteria for institutional success. Factors of importance include stable macro-economic policy that include debt and fiscal stability; secure property rights (Máté, Oláh, Lakner, \& Popp, 2017); strength in budget control; quality in overall governance; accountability (Sadaf, Oláh, Popp, \& Máté, 2018); prevention of corruption; creation of an empowering environment for business development; and social protection. Furthermore, to mention, the role of expenditure on education (Karaçor et al., 2018) as well as the level of exports (Kabaklarli et al., 2018).
With regards to empirical results from similar and previous studies, several are available in the literature. According to Chong and Calderon (2000), a bi-directional causality exists between strong and effective institutions (good governance) and economic growth. This finding is supported by Levine (1997). Evans and Rauch (2000) also found a significant correlation between effective governance and economic growth. Kaufman and Kraay (2002), discovered that good governance is crucial for economic growth and in fact causes economic growth. AlMarhubi (2004), confirmed that economic growth is one of the factors that has a significant impact on good governance. Kurtz and Schrank (2007) state that effective government could be achieved by means of effective public management and economic growth can lead to more effective government. Cooray (2009) also concluded, that effective and good governance positively effects economic growth. Abizadeh and Yousefi (1998) state that a large ineffective public sector, has the potential to negatively impact economic growth. Seldadyo, Nugroho \& De Haan, (2007) studied the governance-growth relationship and found that effective government activities had a significantly positive impact on economic growth. Government size and interventions should therefore be limited.

Moreover, research confirmed that corruption is concomitant with relatively weak governance and related low levels of economic growth and investment (Friedman et al., 1999; Mauro, 1995). Corruption is any activity in the public sector that is used to the benefit of individuals and includes bribery, nepotism, and theft of public resources (Drury et al., 2006). The impact of corruption negatively impacts the effectiveness of government (Mauro, 1997), and limits economic growth (Meyer, Meyer and Molefe, 2016). Aidt (2009) also found that economic growth lead to less corruption. The existence of law and order, protection of property rights and policy certainty also attracts growth and investment (Knack \& Keefer, 1995), (Máté, Kun, \& Fenyves, 2016). This finding is confirmed by Aguilera and Cuervo-Cazurra, (2004) who indicate that good governance is possible when all components of law and order exist which include property and civil rights. 
Cooray (2009) analysed the role and relationship between government activities and economic growth and used the size of government, where the size of government is measured by government expenditure. The results found that government size is a significant predictor for economic growth. By improving the capacity and quality of governance, improved growth performance is a possibility. Lin (1994) analysed the effect of government spending on economic growth for both developed and less-developed economies. Results from this study are that government spending positively impacts economic growth on the short specifically, but in this case, not on the long term. Alexiou, (2009) investigated this relationship in the South Eastern Europe (SEE) region. It was found that variables such as spending by government on capital formation, development support, investment by the private sector and lastly trade-openness, have all significant and positive impacts on economic growth. Loizides and Vamvoukas, (2005) tested the Granger causality between government size measured as total expenditure and economic growth in countries that included Greece, Ireland and the UK. The results indicated that the size of government creates economic growth in all the countries in the study. In addition, economic growth produced changes in the size of government in Greece and in the UK. In another study by Afonso and Furceri, (2010), the authors investigated the impacts of government spending on economic growth in all OECD and EU countries. Several variables were included in the study as components of government spending and the results indicated that government investment; subsidies; indirect taxes; government consumption; and social contributions, have a significant and negative impact on growth. In addition to the aforementioned studies, Dzhumashev (2014) found that in low-income economies, increases in government spending can result in reduced economic growth. Further results indicate that government spending can lead to an increase in levels of corruption. Bergh and Henrekson, (2011) analysed the relationship between government size and economic growth. The study found a significant negative correlation and empirically explain that an increase in the size of government by ten percentage points is related to $0.5 \%$ to $1 \%$ reduction in the annual growth rate. No conclusive evidence has therefore been collected to explicitly confirm the effect of the size and expenditure of government on economic growth. The main factor is effective governance and government spending.

In regard to government debt and economic growth, Checherita-Westphal and Rother, (2012) analysed 12 Eurozone countries from 1970 to 2010. The study used a threshold model and found a non-linear impact of debt on growth with a threshold point at ninety to $100 \%$, wherein a negative impact on long-term economic growth is experienced. Additional results indicate that even at debt to GDP ratios of $70 \%$ to $80 \%$ start to have a negative impact on the economy. Panizza and Presbitero, (2013) investigated the linkages between government debt and economic growth in developed countries. They concluded that future research is required, and no clear results were found concerning the relationship between the two variables. Although for most countries included in this study, the impact of rising government debt is negative on economic growth. Lof and Malinen, (2014) analysed the relationship between variables for twenty developed countries and discovered a negative and significant impact of growth on debt. In the continuation of the government debt and economic growth relationship, Ayadi and Ayadi, (2008) examined the relationship in Nigeria and South Africa. The results confirm the negative effect of debt on growth in both countries. South Africa however outperformed Nigeria in the use of debt to facilitate growth. It was also found that debt can contribute positively to growth up to a certain point, after which the contribution becomes negative. Panizza and Presbitero, (2014) scrutinised the relationship in a sample of OECD countries and established a negative relationship between the two variables under investigation.

Grier and Tullock, (1989) analysed a total of 113 countries and investigated government factors affecting economic growth. The results indicate that increases in spending by government has a mostly negative impact on the economy in most of the countries, including the OECD. Lastly, Loayza, Oviedo, and Servén, 
(2005) studied the effect of regulation on economic growth. Informality of business and firms is a vital passage through which regulations may impact the performance of the economy. Findings from this study reveal that higher levels of regulations reduce economic growth and promote informal sector. These effects however be reduced with institutional quality.

Table 3. Summary of variables included in study

\begin{tabular}{|c|c|c|c|}
\hline $\begin{array}{l}\text { Name of } \\
\text { variable }\end{array}$ & $\begin{array}{l}\text { Abbreviation } \\
\text { for variable } \\
\text { (in Log) }\end{array}$ & Data source & Detail description \\
\hline GDP & LGDP & $\begin{array}{l}\text { The World Bank } \\
\text { data set, (2017). }\end{array}$ & $\begin{array}{l}\text { GDP is the gross domestic product for the } \\
\text { country at constant prices in USD. }\end{array}$ \\
\hline $\begin{array}{l}\text { Government } \\
\text { expenditure / } \\
\text { spending }\end{array}$ & LGOVEXP & $\begin{array}{l}\text { The World Bank } \\
\text { data set, (2017). }\end{array}$ & $\begin{array}{l}\text { Government spending is defined as the } \\
\text { government budget expenditure as reported } \\
\text { in the final government accounts. }\end{array}$ \\
\hline $\begin{array}{l}\text { Government } \\
\text { Debt }\end{array}$ & LGOVDEBT & $\begin{array}{l}\text { The World Bank } \\
\text { data set, (2017). }\end{array}$ & $\begin{array}{l}\text { Government debt is defined as total general } \\
\text { government debt to usually finance growth } \\
\text { and development. }\end{array}$ \\
\hline $\begin{array}{l}\text { Government } \\
\text { accountability } \\
\text { index }\end{array}$ & LACCOUNT & $\begin{array}{l}\text { The World Bank } \\
\text { (2018), Worldwide } \\
\text { Governance } \\
\text { Indicators (WGI). }\end{array}$ & $\begin{array}{l}\text { Indicates the level of accountability, } \\
\text { participation in government, the freedom of } \\
\text { expression, and free media. The index ranks } \\
\text { a country's level of accountability on a scale } \\
\text { between }-2.5 \text { and }+2.5 \text {, where }-2.5 \text { indicates } \\
\text { weak levels of accountability and }+2.5 \\
\text { indicates strong accountability. }\end{array}$ \\
\hline $\begin{array}{l}\text { Corruption } \\
\text { control index }\end{array}$ & LCORRPTC & $\begin{array}{l}\text { The World Bank } \\
\text { (2018), Worldwide } \\
\text { Governance } \\
\text { Indicators (WGI). }\end{array}$ & $\begin{array}{l}\text { Indicates the level to which public power is } \\
\text { exercised for private gain, as well as } \\
\text { "capture" of the state. The index ranks } \\
\text { governments level of corruption control on a } \\
\text { scale between }-2.5 \text { and }+2.5 \text {, where }-2.5 \\
\text { indicates weak levels of corruption control } \\
\text { and }+2.5 \text { indicates strong levels of corruption } \\
\text { control. }\end{array}$ \\
\hline $\begin{array}{l}\text { Effective } \\
\text { governance } \\
\text { index (part of } \\
\text { good } \\
\text { governance) }\end{array}$ & LEFFGOV & $\begin{array}{l}\text { The World Bank } \\
\text { (2018), Worldwide } \\
\text { Governance } \\
\text { Indicators (WGI). }\end{array}$ & $\begin{array}{l}\text { Indicates of the quality of service delivery, } \\
\text { civil service performance, policy formulation } \\
\text { and implementation. The index ranks a } \\
\text { country's effectiveness on a scale between - } \\
2.5 \text { and }+2.5 \text {, where }-2.5 \text { indicates weak } \\
\text { government effectiveness and }+2.5 \text { indicates } \\
\text { strong government effectiveness. }\end{array}$ \\
\hline $\begin{array}{l}\text { Size of } \\
\text { Government }\end{array}$ & LSIZEGOV & $\begin{array}{l}\text { The Fraser } \\
\text { Institute, (2018). }\end{array}$ & $\begin{array}{l}\text { The size of government includes } \\
\text { components such as government } \\
\text { consumption, transfers and subsidies, } \\
\text { enterprises and investment and tax rates, } \\
\text { the scale ranges from } 0 \text { to } 10 \text {. }\end{array}$ \\
\hline $\begin{array}{l}\text { Level of } \\
\text { Government } \\
\text { Regulations }\end{array}$ & LGOVREGU & $\begin{array}{l}\text { The Fraser } \\
\text { Institute, (2018). }\end{array}$ & $\begin{array}{l}\text { Level of regulation includes regulations } \\
\text { components such as the credit market, } \\
\text { labour market, and business. The scale } \\
\text { ranges from } 0 \text { to } 10 \text {. }\end{array}$ \\
\hline
\end{tabular}




\section{EMPIRICAL METHODS}

To achieve the empirical objectives of the study, a quantitative methodology is utilized. A quantitative process is followed based on the analysis of secondary data using time series data. The primary aim of the analysis is to determine econometrically, the relationship and impact of government activities and quality of governance on economic output and growth with GDP at constant prices. The study focuses on Poland and uses annual data from 1995 to 2017. GDP is selected as the dependent variable for the study, and the rest of the variables are used as independent variables. Table 3 summarises the variables included in the study.

Basic descriptive statistical analysis and correlation analysis were completed before the econometric analysis was initiated. An Autoregressive Distributed Lag model (ARDL), an econometric time series model, as developed by Pesaran and Shin, (1996) and amended by Pesaran, Shin and Smith (2001) determines the significance of the relationships between the variables. This model has many benefits that include a stable model even when limited number of observations are included in the model. All data were converted to natural logarithms. To determine the relationships between the variables, equation (1) is listed:

$\triangle$ LGDP $=\mathrm{f}(\triangle \mathrm{LGOVEXP}+\triangle \mathrm{LGOVDEBT}+$ $\triangle \mathrm{LACCOUNT}+\triangle \mathrm{LCORRPTC}+\triangle \mathrm{LEFFGOV}+$ $\triangle \mathrm{LSIZEGOV}+\triangle \mathrm{LGOVREGU}$

With the model formulated, the first step is to test for the level of stationarity by means of unit root tests. This test confirms the model selection. Secondly the Bounds test is used to test for any long-run relationships between variables. The next step in the estimation methodology is the evaluation of the error correction model (ECM). The maximum number of lags were estimate and in addition, a number of diagnostic tests, including a normality test, heteroscedasticity test, and serial-correlation test were performed. Lastly, a Todo-Yamamoto (1995) causality analysis was also performed to determine the causality between all of the variables.

\section{RESULTS AND DISCUSSION}

Figure 1 is a graphical indication of the trends in all the variables used in the study. The economic output in Poland has shown constant high growth rates peaking at over 600 Billion USD in 2018. Government expenditure has peaked in 2017 at over USD 103 Billion with only a dip in expenditure in 2010 to 2012. Government debt started slowly from 1996 to 2001, but since 2002 to 2013 has rapidly escalated to a maximum level of USD 295 Billion. The debt levels have since 2014 stabilised and even reduced up to 2017. Level of accountability of governance reached a low point in 2006 to 2007 but recovered from 2007 to 2015. However, since 2015 a rapid decline has been experienced in accountability. Corruption control peaked in 1998 to 1999 but deteriorated up to 2004 to 2005 to a low point, but corruption control levels have steadily increased since 2005 to 2017. Government effectiveness also research a low point in 2006 to 2007 but recovered up to 2014 . The index has however shown a decline since 2014 without recovery. The level of regulations has steadily increased over time but has stagnated since 2013 and are indicate a decline towards 2017. Lastly, the size of government has peaked between 2000 to 2001 and has remained at high levels up to 2017.

This next section provides details of the results of the estimation of the model and discussion of results, linked to previous empirical results. Unit root tests are important econometric tests in the process of selection of the specific model in testing for stationarity. The tests were conducted by using the Augmented Dickey-Fuller (ADF) test. Results from the tests are summarised in Table 4 . Results indicate a mixture of stationarity from the unit root tests, all variables are stationary at either levels $\mathrm{I}(0)$ or at $1^{\text {st }}$ difference I(1). For this reason, an ARDL model are estimated as it was designed to be used in the case where there is a mixture of variables. 
Table 4. Unit root tests

\begin{tabular}{|l|l|l|l|}
\hline Variables & \multicolumn{2}{|l|}{ Stationarity } & Result \\
\hline & ADF levels I (0) & ADF $1^{\text {st }}$ difference I (1) & \\
\hline LGDP & 0.4199 & $0.0049^{*}$ & $\mathrm{I}(1)$ \\
\hline LGOVEXP & 0.5637 & $0.0364^{*}$ & $\mathrm{I}(1)$ \\
\hline LGOVDEBT & 0.7288 & $0.0489^{*}$ & $\mathrm{I}(1)$ \\
\hline LACCOUNT & 0.2103 & $0.0443^{*}$ & $\mathrm{I}(1)$ \\
\hline LCORRPTC & 0.4356 & $0.0056^{*}$ & $\mathrm{I}(1)$ \\
\hline LGOVEFF & 0.6281 & $0.0174^{*}$ & $\mathrm{I}(1)$ \\
\hline LGOVSIZE & $0.0201^{*}$ & $0.0078^{*}$ & $\mathrm{I}(0)$ \\
\hline LGOVREGU & $0.0003^{*}$ & $0.0001^{*}$ & $\mathrm{I}(0)$ \\
\hline
\end{tabular}

Note: *denotes the rejection of the null hypothesis of unit root at the $5 \%$ level of significance.

GDP (US\$ billions)

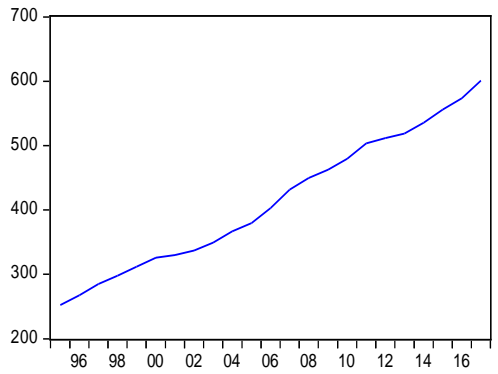

Accountability Index

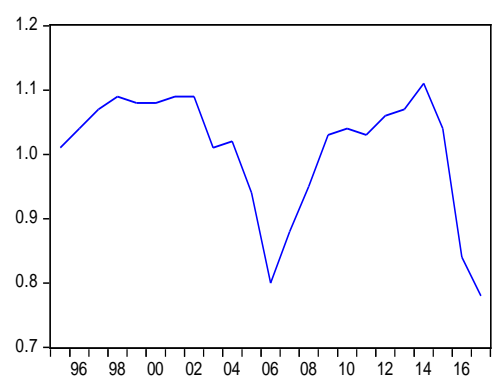

Level of regulations

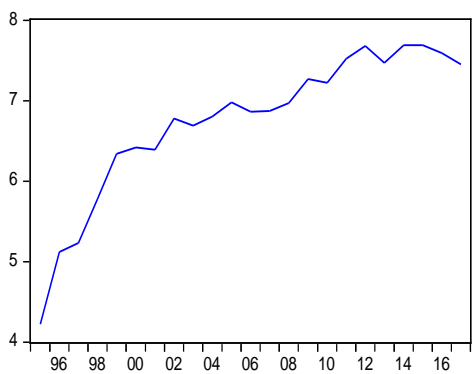

Government expenditure (US\$ billions)

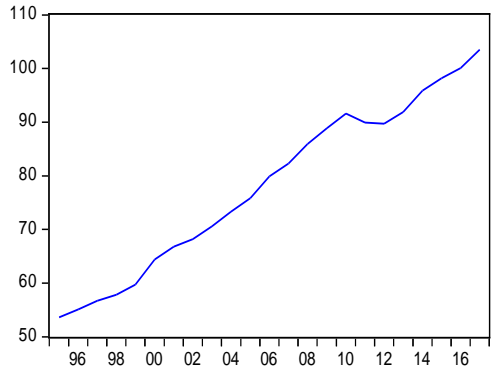

Corruption control Index

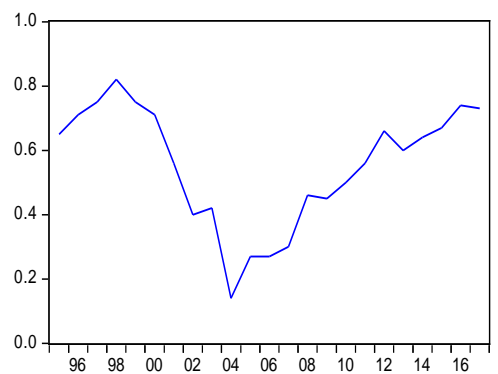

Size of government

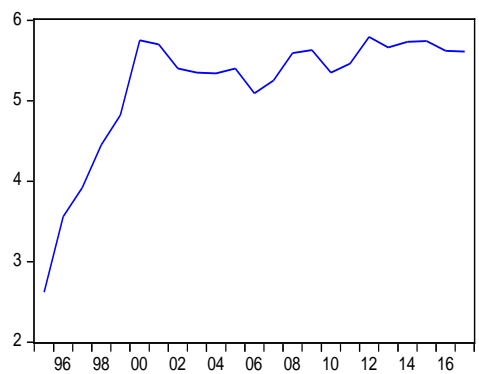

Government debt (US\$ billions)

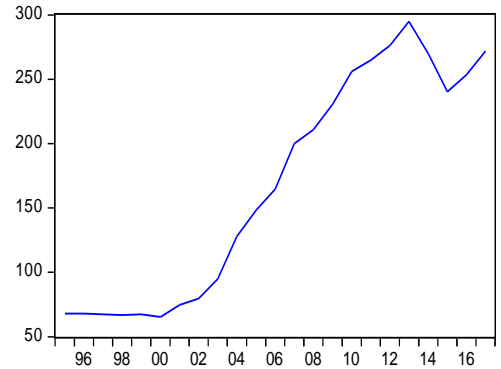

Government effectiveness Index

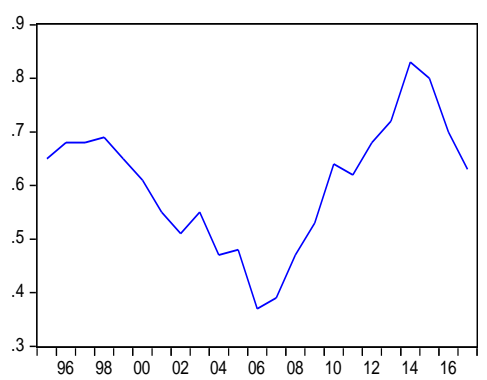

Figure 1. Trend analysis 
The lag length for the model was estimated and all selection criteria, including the Akaike information criterion and Hannan-Quinn information criterion, selected the following as the best fit ARDL model: $(1,1,1,0,0,1,1,1)$. The long-run relationships between variables was estimated using the Bound test of cointegration. According to Pesaran et al. (2001), the estimated F-statistic are compared with the lower and upper bound value at the significance level. The F-statistic was 8.21 with the upper bound value at 5 percent significance at 3.50. It can therefore be concluded that the F-statistic is higher the upper bound value, hence the null hypothesis is rejected. The study concluded that there exists a long-run relationship exists between the variables. Equation (2) represents the long-run relationship:

LGDP $=+2.620+0.486 *$ LGOVEXP +

$0.110 *$ LGOVDEBT $+0.582 *$ LACCOUNT +

$0.027^{*}$ LCORRPTC $+0.215^{*}$ LGOVEFF +

$0.178^{*}$ LGOVSIZE $+0.314^{*}$ LGOVREGU

The results from the long-run equation are interesting and important from a policy standpoint. All the independent variables have a positive long-run effect of GDP. Of all the variables LACCOUNT followed by LGOVEXP have the highest long-run impact on GDP. Interestingly, LCORRPTC has the lowest impact on GDP of all the variables in the model. A $1 \%$ increase in LGOVEXP could lead to a $0.49 \%$ improvement in LGDP and if LGOVDEBT increase by $1 \%$, LGDP will increase by approximately $0.1 \%$ for example. The short-run empirical results are indicated in Table 5. The ECT is negative and significant as required, which confirms a long-run causality from the independent variables to the dependent variable. All variables in the model are cointegrated on the long run. This signifies that it will take approximately $1.2(1 / 0.827)$ periods (years) for changes in the independent variables to affect economic output. On the short run however, more positive results have been estimated. Of the seven independent variables, four of the variables have a significant short-run relationship with GDP namely GOVDEBT, ACCOUNT, CORRUPTC and GOVEFF with ACCOUNT having the highest coefficient of all the variables as included in the model of 0.251 .

Table 5. Short-run relationship and error-correction results

\begin{tabular}{|l|l|l|l|}
\hline Variable & Coefficient & Std. Error & P-value \\
\hline $\mathrm{D}$ (GOVEXP) & 0.264 & 0.143 & 0.102 \\
\hline $\mathrm{D}$ (GOVDEBT $)$ & 0.108 & 0.035 & $0.015^{*}$ \\
\hline $\mathrm{D}$ (ACCOUNT) & 0.251 & 0.059 & $0.003^{*}$ \\
\hline $\mathrm{D}$ (CORRUPT) & 0.035 & 0.010 & $0.009^{*}$ \\
\hline $\mathrm{D}$ (GOVEFF) & 0.178 & 0.039 & $0.002^{*}$ \\
\hline $\mathrm{D}$ (GOVSIZE) & 0.147 & 0.089 & 0.137 \\
\hline $\mathrm{D}$ (REGU) & 0.059 & 0.087 & 0.517 \\
\hline Coint Eq $(-1)$ & $\mathbf{- 0 . 8 2 7 5}$ & $\mathbf{0 . 1 8 7 0}$ & $\mathbf{0 . 0 0 3 1 ^ { * }}$ \\
\hline
\end{tabular}

Note: *rejection of null hypothesis at $5 \%$ level of significance.

Table 6 provides a summary of the Granger Causality results indicating short-run causal relationships between variables. The empirical results of the Granger Causality tests based on Toda and Yamamoto (1995) methodology. This method is used in cases where a mixture of variables exists regarding stationarity. The results listed in the table is only a summary of the results where significant causality was determined between all variables. The results listed in the table only indicates where $5 \%$ and
$10 \%$ significance were recorded between two variables. The results indicate strong causality involving the main dependent variable, GDP. It is interesting to note that GOVEXP, GOVSIZE, GOVEFF, ACCOUNT, GOVREGU all causes changes in GDP. On the other hand, GDP causes GOVSIZE, GOVEFF, and CORRUPTC to move. Many other causality relationships are listed in Table 5 which are important results for policy development. 
Table 6. Toda-Yamamoto Causality Test results

\begin{tabular}{|l|l|l|}
\hline Null hypothesis & Chi-sq & p-value \\
\hline GOVEXP does not granger cause GDP & 7.978 & $0.0047^{*}$ \\
\hline GOVSIZE does not granger cause GDP & 3.716 & $0.0539^{* *}$ \\
\hline GDP does not granger cause GOVSIZE & 7.004 & $0.0081^{*}$ \\
\hline GOVEFF does not granger cause GDP & 8.992 & $0.0027^{*}$ \\
\hline GDP does not granger cause GOVEFF & 6.288 & $0.0122^{*}$ \\
\hline ACCOUNT does not granger cause GDP & 19.963 & $0.0001^{*}$ \\
\hline GOVREGU does not granger cause GDP & 10.602 & $0.0011^{*}$ \\
\hline GOVEXP does not granger cause GOVDEBT & 3.456 & $0.0630^{* *}$ \\
\hline GOVEXP does not granger cause GOVSIZE & 5.613 & $0.0178^{*}$ \\
\hline GOVEFF does not granger cause GOVSIZE & 4.692 & $0.0303^{*}$ \\
\hline GOVEXP does not granger cause GOVEFF & 3.922 & $0.0477^{*}$ \\
\hline ACCOUNT does not granger cause GOVEFF & 14.860 & $0.0001^{*}$ \\
\hline GOVEFF does not granger cause ACCOUNT & 4.612 & $0.0317^{*}$ \\
\hline CORRPTC does not granger cause ACCOUNT & 6.481 & $0.0109^{*}$ \\
\hline GDP does not granger cause CORRPTC & 5.931 & $0.0149^{*}$ \\
\hline GOVEXP does not granger cause CORRPTC & 4.990 & $0.0255^{*}$ \\
\hline
\end{tabular}

Note: ${ }^{*}$ rejection of null hypothesis at $5 \%$ level of significance and ${ }^{* *}$ rejection at $10 \%$ level.

Residual diagnostic tests were performed to

results as indicated in Table 7. confirm the correctness and stability of the

Table 7. Diagnostic and stability tests

\begin{tabular}{|l|l|l|l|}
\hline Test & Hypothesis & Probability & $\begin{array}{l}\text { Decision } \\
\text { No serial correlation }\end{array}$ \\
\hline $\begin{array}{l}\text { Breusch-Pagan- } \\
\text { Godfrey test }\end{array}$ & No heteroscedasticity & 0.2010 & No heteroscedasticity \\
\hline Jaque-Bera test & $\begin{array}{l}\text { Residuals are normally } \\
\text { distributed }\end{array}$ & 0.8744 & $\begin{array}{l}\text { Residuals are normally } \\
\text { distributed }\end{array}$ \\
\hline $\begin{array}{l}\text { CUSUM and } \\
\text { CUSUMSQ }\end{array}$ & $\begin{array}{l}\text { Both models remained within upper and } \\
\text { lower critical boundaries }\end{array}$ & $\begin{array}{l}\text { Models are stable at } 0.05 \\
\text { level of significance }\end{array}$ \\
\hline
\end{tabular}

The Breusch-Godfrey LM Test was performed to test for serial correlation, the Breusch-PaganGodfrey Test was estimated to test for heteroscedasticity amongst the variables and the Jarque-Bera Test was performed to test for normal distribution. The results revealed that for the series as used, the residuals are not auto correlated, the series was homoscedastic and normally distributed. Lastly, the CUSUM test was applied to assess parameter stability and test results indicates stability for the model. This indicates that the findings are trustworthy.

In summary, the following outcomes are listed from the quantitative analysis. The trend analysis indicates that GDP, government expenditure and government debt follow similar trends in their graphs, while the accountability index, corruption control index and government effectiveness index also projects similar flowing charts. Lastly, the level of regulations and size of government have similar trends. Long-run analysis via the Bounds 
test indicates cointegration of the variables included in the model with all seven independent variables having a positive relationship with the dependent variable, namely GDP. Government accountability and government expenditure had the highest impact on GDP of the seven predicting variables, while corruption control had the lowest but also positive impact. If the long-run results are compared with the short-run results some differences are evident. Only four of the seven independent variables are significant predictors of GDP in this study. The variable with the highest impact on the short-run is government accountability (same as on the long-run), followed by government effectiveness and government debt. Interesting to note is that long-run predictors government expenditure, government size and level of regulations does not affect GDP on the short-run. In terms of causality, also a short-run analysis, all the independent variables do cause GDP to move except for government debt and corruption control. On the other hand, GDP does cause changes in government size, government effectiveness and corruption control levels.

\section{CONCLUSION}

Literature and empirical results from previous studies indicate the importance of good governance and quality institutions for economic progress and success. The main objective of this study was to determine using an econometric methodology, the impact of different types of variables related to government activities on the economy. The analysis provided interesting results on the long and short run. The results indicate a long-run relationship amongst the variables, while in the short-run it was found in that variables such as government debt, accountability, corruption control and effective government have a significant impact on economic growth. Important variables such as government expenditure, government size and regulations did not significantly affect economic growth. The results also confirmed that most of the independent variables Granger cause changes in GDP.

The implications of the study are that effective government, through strong public institutions, can play a significant role in economic growth and development as proven in this study by using seven government related variables to analyse the relationships. The limitation of the study is that the time frame is from 1995 due to availability of data. Future research should include other variables such as government risk factors and some comparative and panel studies including groupings of countries. In terms of comparative studies, it is planned to perform an analysis of the Visegrád countries, and to compare these countries to other European states as well as with developing countries such as South Africa and the BRICS group. The focus of such studies may also be amended by using GDP per capita as the dependent variable as a proxy for economic development. In addition, future studies possibly will analyse the impact on specific sectors of the economy.

In conclusion, it is confirmed from the study results that good governance is critical to achieve growth, less corruption and political instability. All efforts should be made to ensure good public institutions which are transparent, accountable, limited interference in the economy, and that can ensure rule of law. Effective government must ensure fiscal discipline, have a decentralized governance system, respond to the needs of citizens and formulate and implement empowering environment policies for the private sector to prosper. Possible effective policies may include further trade liberalization, business development incentives, reduction of regulations and substantial investments in critical economic sectors such as infrastructure, defence, and energy. Aspects for continued growth include the removal of backlogs in infrastructure, relaxation of strict labour and other regulations, limited government interventions, quality non-political officials, stable macro-economic policy including debt and fiscal stability, strength in budget control and social protection. Finally, effective government debt may contribute positively to growth up to a certain point, after which the contribution becomes negative and high levels of regulations reduces economic growth and the promotion of informal sector. Any of these negative effects can however, be reduced by means of institutional quality. 


\section{REFERENCES}

Abizadeh, S. \& Yousefi, M. (1998). An empirical analysis of South Korea's economic development and public expenditures growth. The Journal of Socio-Economics, 27(6), 687-700.

Afonso, A. \& Furceri, D. (2010). Government size, composition, volatility and economic growth. European Journal of Political Economy, 26(4), 517-532.

Aguilera, R.V. \& Cuervo-Cazurra, A. (2004). Codes of good governance worldwide: what is the trigger? Organization Studies, 25(3), 415-443.

Aidt, T.S. (2009). Corruption, institutions, and economic development. Oxford Review of Economic Policy, 25(2), 271-291.

Alexiou, C. (2009). Government spending and economic growth: Econometric evidence from the South Eastern Europe (SEE). Journal of Economic and Social Research, 11(1), 1-10.

Al-Marhubi, F. (2004). The Determinants of Governance: A Cross-Country Analysis. Contemporary Economic Policy, 22(3), 394406.

Andrews, M. (2008). The good governance agenda: Beyond indicators without theory. Oxford Development Studies, 36(4), 379407.

Arndt, C. \& Oman, C. (2006). Uses and Abuses of Governance Indicators, Paris: OECD. OECD Development Center Studies.

Ayadi, F.S. \& Ayadi, F.O. (2008). The impact of external debt on economic growth: A comparative study of Nigeria and South Africa. Journal of Sustainable Development in Africa, 10(3), 234-264.

Bergh, A. \& Henrekson, M. (2011). Government size and growth: a survey and interpretation of the evidence. Journal of Economic Surveys, 25(5), 872-897.

Besancon, M. (2003). Good governance rankings. The art of Measurement. World Peace Foundation. WPF Reports, 36. http://www.innovations.harvard.edu/sites/d efault/files/.pdf. Date of access: 15.03.2019.
Brinkerhoff, D. \& Goldsmith, A. (2005). Institutional dualism and international development: a revisionist interpretation of good governance. Administration \& Society, 37, 199-224.

Central Intelligence Agency (CIA). (2017). The World Fact Book, Country Profiles. https://www.cia.gov/library/publications/th e-world-factbook/geos/sf.html. Date of access: 18.02.2019.

Checherita-Westphal, C. \& Rother, P. (2012). The impact of high government debt on economic growth and its channels: An empirical investigation for the euro area. European Economic Review, 56(7), 1392-1405.

Chong, A. \& Calderón, C. (2000). Causality and Feedback Between Institutional Measures and Economic Growth. Economics and Politics, 12, 69-81.

Cooray, A. (2009). Government expenditure, governance and economic growth. Comparative Economic Studies, 51(3), 401418.

DFID. (2001). Making Government Work for Poor People: Building State Capacity. Strategy Paper. London: DFID.

Drury, A.C., Krieckhaus, J. \& Lusztig, M. (2006). Corruption, democracy, and economic growth. International Political Science Review, 27(2), 121-136.

Dzhumashev, R. (2014). The Two-Way Relationship between Government Spending and Corruption and Its Effects on Economic Growth. Contemporary Economic Policy, 32(2), 403-419.

Eichner, A.S. \& Kregel, J.A. (1975). An essay on post-Keynesian theory: a new paradigm in economics. Journal of Economic Literature, 13(4), 1293-1314.

Friedman, E., Johnson, S., Kaufmann, D. \& ZoidoLobatón, P. (1999). Dodging the Grabbing Hand: The Determinants of Unofficial Activity in 69 Countries, Journal of Public Economics, 76(3), 459-93.

Grier, K.B., \& Tullock, G. (1989). An empirical analysis of cross-national economic growth, 1951-1980. Journal of Monetary Economics, 24(2), 259-276. 
Grindle, M.S. (2007). Good enough governance revisited. Development Policy Review, 25(5), 533-574.

International Monetary Fund (IMF). (2005). Good Governance: The IMF's Role. http://www.imf.org/external/pubs/ft/exrp/g vern/govindex.htm. Date of access: 13.04.2019.

Kabaklarli, E., Sami Duran, M., \& Telli Üçle, Y. (2018). High-technology exports and economic growth: panel data analysis for selected OECD countries, Forum Scientiae Oeconomia, 6(2), 47-60. DOI: 10.23762/FSO_VOL6NO2_18_4

Karaçor, Z., Güvenek, B., Ekinci, E., \& Konya, S. (2018). Panel estimation for the relationship between education expenditure and economic growth for OECD countries, Forum Scientiae Oeconomia, 6(2), 7-20. DOI: 10.23762/FSO_VOL6NO2_18_1

Kaufmann, D. \& Kraay, A. (2002). Growth without Governance. World Bank Policy Research Working Paper No. 2928. Washington, DC: World Bank.

Kaufmann, D. Kraay, A. \& Mastruzzi, M. (2007). The Worldwide Governance Indicators Project: Answering the Critics, World Bank Policy Research Working Paper 4149.

Knack, S. \& Keefer, P. (1995). Institutions and Economic Performance: Cross-country Tests Using Alternative Institutional Measures. Economics and Politics, 7, 207-227.

Kurtz, M.J. \& Schrank, A. (2007). Growth and governance: Models, measures, and mechanisms. Journal of Politics, 69(2), 538554.

Levine, R. (1997). Law, Finance and Economic Growth. Washington, DC: World Bank.

Lin, S.A. (1994). Government spending and economic growth. Applied Economics, 26(1), 83-94.

Loayza, N.V., Oviedo, A.M. \& Servén, L. (2005). The Impact of Regulation On Growth And Informality-Cross-Country Evidence, Vol. 1 Of 1. The World Bank.

Lof, M. \& Malinen, T. (2014). Does sovereign debt weaken economic growth? A panel VAR analysis. Economics Letters, 122(3), 403-407.
Loizides, J. \& Vamvoukas, G. (2005). Government expenditure and economic growth: Evidence from trivariate causality testing. Journal of Applied Economics, 8(1), 125-152.

Máté, D., Kun, A. I., \& Fenyves, V. (2016). The Impacts of Trademarks and Patents on Labour Productivity in the Knowledgeintensive Business Service Sectors. Amfiteatru Economic, 18(41), 104-119.

Máté, D., Oláh, J., Laknern, Z., \& Popp, J. (2017). Food chemistry patents influence on productivity: A case study of a sectoral approach in various OECD countries. Polish Journal of Management Studies, 16(2). https://doi.org/10.17512/pjms.2017.16.2.14

Mauro, P. (1995). Corruption and Growth, Quarterly Journal of Economics, 110, 681712.

Mauro, P. (1997). Why worry about corruption? Economic Issues no 6. Washington, DC: International Monetary Fund.

Meyer, N., \& Meyer, D.F. (2016). The relationship between the creation of an enabling environment and economic development: A comparative analysis of management at local government sphere. Polish Journal of Management Studies, 14(2), 150-159.

Meyer, N., Meyer, D.F. \& Molefe, K.N. (2016). Barriers to small informal business development and entrepreneurship: The case of the Emfuleni Region. Polish Journal of Management Studies, 13(1), 121-133.

Nash, R., Hudson, A. \& Luttrell, C. (2006). Mapping Political Context: A Toolkit for Civil Society Organisations. London: Overseas Development Institute.

NationMaster. (2017). Country profiles. http://www.nationmaster.com/countryinfo/profiles. Date of access: 19.02.2019.

Nölke, A., \& Vliegenthart, A. (2009). Enlarging the Varieties of Capitalism: The Emergence of Dependent Market Economies in East Central Europe. World Politics, 61(4), 670702.

Panizza, U., \& Presbitero, A. F. (2014). Public debt and economic growth: is there a causal effect? Journal of Macroeconomics, 41, 2141. 
Panizza, U., \& Presbitero, A.F. (2013). Public debt and economic growth in advanced economies: A survey. Swiss Journal of Economics and Statistics, 149(2), 175-204.

Pesaran, M.H., Shin, Y. \& Smith, R.J. (2001). Bounds testing approaches to the analysis of level relationships. Journal of Applied Econometrics, 16(3), 289-326.

Pesaran, M.H., Shin, Y. (1996). Cointegration and speed of convergence to equilibrium. Journal of Econometrics, 71(1), 117-143.

Rosenstein-Rodan, P.N. (1961). Notes on the theory of the 'big push'. In Economic Development for Latin America (pp. 57-81). Palgrave Macmillan, London.

Sadaf, R., Oláh, J., Popp, J., \& Máté, D. (2018). An investigation of the influence of the worldwide governance and competitiveness on accounting fraud cases: A cross-country perspective. Sustainability, 10(3). https://doi.org/10.3390/su10030588

Sambumbu, A. M., \& Okanga, B. (2016). Integrated strategies for managing the implementation of the national development plan. Journal of Contemporary Management, 13(1), 866-891.

Seldadyo, H., Nugroho, E. P. \& De Haan, J. (2007). Governance and growth revisited. Kyklos, 60(2), 279-290.

Sutopo, B. \& Siddi, P. (2018). Capital expenditures and performance of local government administration. Polish Journal of Management Studies, 17(1), 221-230.

The Fraser Institute. (2018). The Economic Freedom Index. https://www.fraserinstitute.org/economicfreedom/dataset. Date of access: 10.02.2019.

The Heritage Foundation. (2017). Country Rankings. http://www.heritage.org/index/ranking. Date of access: 10.02.2019.

Thomas, M.A. (2007). What Do the Worldwide Governance Indicators Measure? John Hopkins University-Paul H. Nitze School of Advanced International Studies (SAIS) Working Paper. http://ssrn.com/abstract=1007527. Date of access: 11.07.2018.
Toda, H.Y., \& Yamamoto. (1995). Statistical inference in Vector Autoregressions with possibly integrated processes. Journal of Econometrics, 66, 225-250.

Transparency International. (2018). https://www.transparency.org/. Date of access: 11.02.2019

UNDP. (1997). Governance for Sustainable Human Development, A UNDP policy paper UNDP.

UNDP. (2018). Human Development Index (HDI). http://hdr.undp.org/en/content/humandevelopment-index-hdi. Date of access: 12.03.2019

United Nations. (2017). Country classifications. http://www.un.org/en/development/ country_classification.pdf. Date of access: 10.03.2019.

USAID. (2005). Democracy and Governance. http://www.usaid/gov/. Date of access: 08.04.2019.

World Bank. (2000). Reforming public institutions and strengthening governance. World Bank. https://scholar.google.com/scholar/World. Date of access: 15.06.2018.

World Bank. (2017). World Bank Open Data. https://data.worldbank.org/. Date of access: 11.04.2019.

World Bank. (2018). Worldwide Governance Indicators. http://info.worldbank.org/. Date of access: 11.05.2019.

\section{ABOUT THE AUTHOR}

Daniel Francois Meyer, email: daniel.meyer@nwu.ac.za

Dr. Daniel Francois Meyer is an Associate Professor and Director of TRADE, research entity at the North West University, South Africa. 